\title{
A Comparative Study of Composts Prepared from Various Organic Wastes Based on Biological and Chemical Parameters
}

\author{
Monika Jakubus $\mathbb{D}$ \\ Department of Soil Science and Land Protection, Poznan University of Life Sciences, ul. Szydłowska 50, \\ 60-656 Poznań, Poland; monika.jakubus@up.poznan.pl
}

Received: 7 May 2020; Accepted: 16 June 2020; Published: 18 June 2020

\begin{abstract}
One of the principles of the circular economy requires the effective recycling of organic waste, especially since its volume is increasing from year to year. Therefore, one of the best solutions to solve this problem is the composting of organic waste. This paper presents the results of a comparative study of 10 different composts in terms of their quality. The composts varied with regard to waste materials used for composting, the adopted composting method, and the degree of compost maturity. Both biological (seed germination rate and intensity of plant root growth) and chemical methods (contents of macro- and micronutrients, presence of heavy metals, as well as the quality and quantity of humus compounds) were applied to evaluate the fertilisers, providing comprehensive characteristics of individual composts. It was found that composts prepared on the basis of sewage sludge had the highest contents of macro- and micronutrients as well as heavy metals. In addition, these composts contained the greatest amounts of humic substances, although these were of low quality. These composts also strongly inhibited seed germination and plant root growth. The least desirable chemical composition was found for the composts based on yard trimmings and household wastes prepared in home composters. These composts contained good quality humus compounds and had a positive effect on seed germination and plant root growth.
\end{abstract}

Keywords: biowastes; sewage sludge; composts; quality; biotest; agriculture

\section{Introduction}

Intensive and quick urbanisation is not only observed in developing countries, but also in those of the former communistic block, such as Poland. Unfortunately, the intensive development of cities is accompanied by a number of negative phenomena, among them primarily rapidly growing amounts of municipal solid waste (MSW) and sewage sludge (SS) [1,2]. Currently due to the rapid increase in the mass of municipal solid waste, it must be perceived as a multidimensional global problem, and proper waste management needs to be developed to attain such goals as the prevention of waste generation and reduction of its volume, increasing resource efficiency, diminishing the quantity of waste intended for landfills, as well as encouraging its reuse and raw material recovery. The principles of circular economy and the assumptions of the zero waste program [3] are helpful, because recyclable materials are reintroduced into the economy as new raw materials, thus increasing the security of their supply. Taking the above into consideration, in addition to plastic, paper, glass, and metals, biowaste is increasingly being sorted in municipalities as well. Thanks to adapting such a system of municipal waste collection in recent years, the mass of biowastes has significantly increased in Poland, amounting in 2018 to $28.4 \%$ of total mass [4]. It presents a new challenge, because according to the Landfill Directive [5], the EU member states are obliged to reduce the amount of biodegradable municipal waste going to landfills and simultaneously alternative strategies should be developed, such as 
composting (including fermentation), incineration and pre-treatment, e.g., mechanical-biological treatment (including physical stabilisation). As indicated by data given on the Bio-waste in Europe website [6], across the European Union, somewhere between 118 and 138 million tonnes of biowaste are generated annually, of which currently about $25 \%$ are composted or digested yearly, with composting predominating over anaerobic digestion. In Poland, composting also prevails and is dedicated to organic wastes. Due to the fact that the group of organic waste is large and diversified, two separate subgroups of biowaste and biodegradable wastes can be distinguished within it. Biowastes are obligatory collected selectively by residents and include garden and park wastes, food, and kitchen wastes from households and restaurants. In contrast, biodegradable wastes include both wastes collected selectively by residents (paper, cardboard) and those resulting from agricultural and forestry activities (forestry and agricultural residue) or municipal wastewater treatment (sewage sludge).

Urbanisation and agglomeration processes, enhancing wastewater infrastructure development as well as the introduction of more advanced methods of municipal wastewaters purification, are factors playing a major function in the increase of sewage sludge mass. This biodegradable, noxious waste should also be considered as an additional civilisation-related problem, because landfills are the least desirable manner of SS utilisation and for example in Poland according to the Polish legal regulations [7], starting from 2016 such wastes may not be deposited at landfills. In order to implement sewage sludge application for environmental purposes, it is a very important strategy to comply with the above-mentioned Landfill Directive [5] and the principles of the circular economy. In Poland in 2018, of the total SS mass generated, almost 30\% were used for applications in the natural environment, e.g., agriculture, land reclamation, or the cultivation of plants intended for composting [4].

Regardless of organic waste type, the best and most sustainable method of their utilisation seems to be the composting process, because it allows reusing their potential by incorporating nutrients and organic matter into circulation while maintaining the waste-soil-plant production continuum. The composting process has been presented as an environmentally friendly alternative applied to manage and recycle organic waste to obtain products used as amendments in agriculture $[8,9]$. Thomas et al. [10] listed positive aspects related to the utilisation of recycling organic wastes as crop fertilisers. Among other things, the cited authors pointed to the reduction of greenhouse gas emissions or enhanced carbon sequestration. Most studies [2,11-13] clearly demonstrate that soil amendment with compost affects various soil properties, including physical, chemical, physicochemical, and biological, especially enhancing TOC, Ntot amounts, and the contents of available macronutrients ( $\mathrm{N}$ mineral, $\mathrm{P}$, $\mathrm{K}, \mathrm{S}, \mathrm{Mg}$ ). Despite many positive aspects connected with compost application, some disadvantages should also be underlined. Obviously, its slow mineralisation and the resulting sluggish progress of nutrient release diminish the agricultural value of composts. Especially the low level of nitrogen is of importance in this respect and thus to meet nitrogen requirements of crops, composts must be applied at higher rates [13]. However, bigger doses of composts may be accompanied by the introduction of larger amounts of undesirable metals such as $\mathrm{Cd}, \mathrm{Cr}$, and $\mathrm{Pb}$, which are also present in compost composition [2]. In view of the above, it is essential to evaluate the quality of composts prior to soil application, which is required because of the vast variability in the chemical composition of organic wastes used for compost production. The above-mentioned diversity results from the origin of various raw materials and the technologies applied to convert wastes into organic fertiliser [14]. In Poland, the composting process may be carried out in both technologies: large-scale commercial (composting facilities) and small-scale household facilities (home composters). Commercially produced composts are always certified products used for agriculture and horticulture, the reclamation of industrial areas, as well as the maintenance of municipal green areas. Composts from home composters do not undergo any evaluation, since they are only used in home gardens as fertilisers in the small-scale growing of vegetables and ornamental plants.

Regardless of the chemical composition and used technology, only the application of stable and mature compost can improve soil fertility by increasing soil organic matter, suppressing soil-borne plant pathogens and enhancing plant growth. However, immature compost may have adverse effects on plant 
growth and the environment because of the presence of phytotoxic compounds, low molecular weight organic acids, ethylene oxide, and pathogens [15]. Maturity refers to the degree of decomposition of phytotoxic organic substances produced during the active composting phase and to the absence of pathogens. Stability is related to the rate of microbial activity in compost, and it is evaluated by different respirometric measurements and/or by studying transformations in chemical properties $[15,16]$. Various and numerous methods have been used to determine the maturity and stability of composts. Jakubus [17] reviewed these methods and distinguished four groups concerning physical parameters (temperature, colour, moisture, content, and aeration); chemical parameters (C:N ratio, $\mathrm{NH}_{4}: \mathrm{NO}_{3}$ ratio, cation exchange capacity- $\mathrm{CEC}, \mathrm{pH}$, electrical conductivity- $\mathrm{EC}$, and humification indexes); microbiological parameters (respiration analysis, ATP content, and enzyme activities) and biological parameters (germination index and plant growth bioassay). In view of the above, there are different methods that in routine practice are difficult to apply simultaneously. Nowadays, methods that will be fast, simple, cheap, and at the same time provide real and repeatable results are sought for and required. Considering the compost soil application and its impact on this environment, compost evaluation should be based on an assessment of nutrient abundance. Moreover, information on the phytotoxic effect of composts as well as the intensity and direction of transformation of organic matter introduced into the soil is also important [11]. Thus, the main aim of this study was to valorise 10 various composts using selected chemical and biological parameters in terms of their fertilising quality and potential usability for application in horticulture, agriculture, or land reclamation. The analysed composts were prepared from commonly used wastes (garden and park waste) as well as those less popular (sewage sludge and spent mushroom substrate). The performed qualitative evaluation made it possible to differentiate composts among themselves, regardless of the raw materials used for composting. In addition, an attempt was made to assess the usefulness of the indicators used in the practical assessment of compost maturity and stability.

\section{Material and Methods}

\subsection{Composting Procedure and Raw Materials}

Ten different composts prepared from various organic wastes using different technologies were analysed in this study. Two composting methods were applied: aerobic composting (AC) and aerobic-anaerobic composting (AANC). The aerobic composting process was applied mainly for such wastes as garden and park waste (cut grass, leaves, shredded branches, plant residues), paper and cardboard collected from the local municipality containers or bags as well as forestry and agricultural residue. In addition, less conventional materials (municipal sewage sludge and spent mushroom substrate) have been used for composting, and they are an alternative substance proposed for compost production and then practical use. The raw materials were mechanically chopped into smaller size particles to ensure the preferred particle size in the range of $15-40 \mathrm{~mm}$. Next, the mixture was placed in long narrow piles called windrows. In the aerobic method, compost piles were prepared as static, triangular-shaped profiles with approximate dimensions of $8 \mathrm{~m} \times 1.2 \mathrm{~m} \times 3 \mathrm{~m}$ (length $\times$ height $\times$ width). Before the formation of the compost piles, all organic materials were thoroughly mixed. Using a specialised Backhus compost mixing machine, the piles were mixed weekly during the first month to ensure adequate aeration conditions, while subsequently the process was performed at monthly intervals. The moisture content of the composted mixture was measured using a moisture meter. Moisture content in the piles was adjusted by adding the amount of water required to obtain $60-70 \%$ of dry matter (water was applied as needed to maintain the respective moisture level). In the aerobic-anaerobic method, composts were prepared as a fertiliser for their home gardens by private homeowners. The composting process was carried out in home composters made of thermoplastic. The organic material (bigger particles were chopped into smaller ones, maximum size of $15-40 \mathrm{~mm}$ ) was successively collected in containers without any mixing of the bulk volume. This established a crust on the upper layer, leading to the development of anaerobic conditions in the center of the container, 
whereas the top layer was exposed to ambient air and thereby to aerobic conditions. Under such conditions, the organic waste mixture was kept for a year. After this time, the whole mass was mixed to homogenise it and then transferred to dark plastic bags to complete the maturation stage. The analysed composts also differed in their degree of maturity. All composts except for composts number 7 and 8 were prepared in composting facilities for commercial purposes. The used raw materials, composting technology, as well as the length of the maturation period followed standards of the individual composting process carried out and were not subject to the researcher's interference. The detailed information concerning the used material and technology are given in Table 1.

Table 1. Raw materials and methods used for individual composts. AC: aerobic composting, AANC: aerobic-anaerobic composting.

\begin{tabular}{|c|c|c|c|}
\hline Compost Number & Raw Materials Used & Method & Maturation Period \\
\hline $\mathrm{C} 1$ & $\begin{array}{l}\text { Mixed biodegradable wastes (wood, paper, } \\
\text { cardboard, forestry, and agricultural } \\
\text { residue) and biowastes (garden and park } \\
\text { wastes, food and kitchen wastes from } \\
\text { households and restaurants) collected } \\
\text { separately by inhabitants of a } \\
\text { medium-sized town }\end{array}$ & $\mathrm{AC}$ & $\begin{array}{l}\text { approximately } 2 \text { months } \\
\text { depending on weather conditions }\end{array}$ \\
\hline $\mathrm{C} 2$ & As above & $\mathrm{AC}$ & $\begin{array}{l}\text { approximately } 4 \text { months } \\
\text { depending on weather conditions }\end{array}$ \\
\hline $\mathrm{C} 3$ & $\begin{array}{l}\text { Composition as above, but collected } \\
\text { separately by inhabitants of a large city }\end{array}$ & $\begin{array}{l}\text { Composting process under } \\
\text { controlled bioreactor conditions } \\
\text { until the completion of the cooling } \\
\text { phase of composting }\end{array}$ & $\begin{array}{l}\text { The maturation stage of compost } \\
\text { run in an open shed and lasting } \\
2 \text { months depending on } \\
\text { weather conditions }\end{array}$ \\
\hline $\mathrm{C} 4$ & As above & $\mathrm{AC}$ & $\begin{array}{l}\text { Approximately } 4 \text { months, } \\
\text { depending on weather conditions }\end{array}$ \\
\hline $\mathrm{C} 5$ & $\begin{array}{l}\text { Mixture of municipal sewage sludge and } \\
\text { biowastes (garden and park wastes, food } \\
\text { and kitchen wastes from households and } \\
\text { restaurants) collected separately. Mixture } \\
\text { prepared in a 1:1 ratio }\end{array}$ & $\mathrm{AC}$ & $\begin{array}{l}\text { Approximately } 6 \text { months, } \\
\text { depending on weather conditions }\end{array}$ \\
\hline C6 & $\begin{array}{l}\text { Mixture of municipal sewage sludge, } \\
\text { biowastes (garden and park wastes, } \\
\text { food and kitchen wastes from households } \\
\text { and restaurants) collected separately and } \\
\text { straw. Mixture prepared in a 1:1:1 ratio }\end{array}$ & $\mathrm{AC}$ & As above \\
\hline $\mathrm{C} 7$ & $\begin{array}{l}\text { Mixture of biowastes (food scraps from } \\
\text { kitchen, and yard trimmings as plant } \\
\text { residues excluding mowed grass clippings) }\end{array}$ & AANC & $\begin{array}{l}\text { Approximately } 1 \text { year depending } \\
\text { on weather conditions }\end{array}$ \\
\hline $\mathrm{C} 8$ & $\begin{array}{l}\text { Mixture of biowastes (food scraps from } \\
\text { kitchen, and yard trimmings as plant } \\
\text { residues and mowed grass clippings) }\end{array}$ & AANC & As above \\
\hline C9 & $\begin{array}{l}\text { Mixture of biowastes (garden and park } \\
\text { wastes, food and kitchen wastes from } \\
\text { households and restaurants) collected } \\
\text { separately and manure. Mixture prepared } \\
\text { in a 1:1 ratio }\end{array}$ & $\mathrm{AC}$ & $\begin{array}{l}\text { Approximately } 6 \text { months } \\
\text { depending on weather conditions }\end{array}$ \\
\hline $\mathrm{C} 10$ & $\begin{array}{l}\text { Compost prepared on spent } \\
\text { mushroom substrate }\end{array}$ & $\mathrm{AC}$ & As above \\
\hline
\end{tabular}

Composted samples were collected after the maturation stage from individual composting facilities and private gardens. Subsamples were collected from places located at equal distances from each other being on the top, middle, and bottom of each composting pile and then the three, approximately $100 \mathrm{~g}$ samples were mixed together precisely to create one mean bulk sample of approximately $300 \mathrm{~g}$. In the case of composts prepared by the AANC method, the samples were taken from the bags after their contents had been mixed.

The samples of composts were divided into fresh and dry samples, and the latter were dried at $105^{\circ} \mathrm{C}$ for a period of $12 \mathrm{~h}$. The dried samples was ground into a fine powder and stored in plastic bags at a temperature of $4{ }^{\circ} \mathrm{C}$. 


\subsection{Chemical Analysis of Compost}

The chemical analyses were conducted on dried samples. The loss-on-ignition test was used to determine organic matter $(\mathrm{OM})$ in composts. For this purpose, compost samples were subjected to dry combustion for $6 \mathrm{~h}$ at a temperature of $550{ }^{\circ} \mathrm{C}$. Total organic carbon (TOC), nitrogen (N), and sulphur (S) contents were assayed using a Vario Max CNS elemental analyser. To determine the amounts of macro- and micronutrients as well as heavy metals in analysed materials, the composts were ground and ashed in a furnace at $450^{\circ} \mathrm{C}$ for $6 \mathrm{~h}$. The ash was dissolved in $5 \mathrm{~mL}$ of $6 \mathrm{~mol} \cdot \mathrm{dm}^{3} \mathrm{HCl}$ and diluted to a constant volume with distilled water [18]. The obtained extracts were analysed to determine the amounts of macronutrients $(\mathrm{K}, \mathrm{Ca}, \mathrm{Mg}, \mathrm{Na})$, micronutrients $(\mathrm{Fe}, \mathrm{Mn}, \mathrm{Zn}, \mathrm{Cu}, \mathrm{Ni})$, and heavy metals $(\mathrm{Pb}$, $\mathrm{Cd})$ using atomic absorption spectrophotometry in a Varian Spectra AA 220 FS apparatus. The total phosphorus $(\mathrm{P})$ content was measured colorimetrically by the vanadium-molybdenum method [18].

Humus fractionation was performed according to the method proposed by Kononova and Bielczikova, in which humic substances (HS) were determined in a mixture of $0.1 \mathrm{~mol} \cdot \mathrm{dm}^{-3} \mathrm{Na}_{4} \mathrm{P}_{2} \mathrm{O}_{7}+$ $0.1 \mathrm{~mol} \cdot \mathrm{dm}^{-3} \mathrm{NaOH}$ solution $[19,20]$. The fulvic acid fraction (FA) was separated after the precipitation of humic acids at $\mathrm{pH} 1.5$ (HA). Carbon in the obtained fractions $\left(\mathrm{C}_{\mathrm{HS}}\right.$ and $\left.\mathrm{C}_{\mathrm{FA}}\right)$ was oxidised by $0.1 \mathrm{~mol} \cdot \mathrm{dm}^{-3} \mathrm{KMnO}_{4}$ in the $\mathrm{H}_{2} \mathrm{SO}_{4}$ medium. Humic acid carbon $\left(\mathrm{C}_{\mathrm{HA}}\right)$ was calculated by subtracting $\mathrm{C}_{\mathrm{FA}}$ from $\mathrm{C}_{\mathrm{HS}}$. The optical density $\left(\mathrm{Q}_{4 / 6}\right)$ of the obtained fractions was determined at $465 \mathrm{~nm}$ and $665 \mathrm{~nm}$. All the assays determining the amounts of individual elements in the tested samples were performed in three replications, and the presented results are their mean values.

The maturity and stability of composts may also be assessed by various humification indexes, which is important when comparing composts produced from similar raw organic materials. Thus, the three popular indexes, i.e., humification ratio (HR), humification index (HI), and degree of polymerisation (DP), were used in these analyses. The humification indexes were calculated using the following equations [21]:

$$
\begin{aligned}
\mathrm{HR}(\%) & =\frac{\mathrm{CHS}}{\mathrm{TOC}} \cdot 100 \\
\mathrm{HI}(\%) & =\frac{\mathrm{CHA}}{\mathrm{TOC}} \cdot 100 \\
\mathrm{DP} & =\frac{\mathrm{CHA}}{\mathrm{CFA}}
\end{aligned}
$$

\subsection{Phytotoxicity Biotests}

In this study, two independent biotests were used to determine the phytotoxicity of composts: the germination index (GI) and the Phytotoxkit [22] evaluating the rate of seed germination inhibition and root growth. The tests were performed using 10 seeds of cress (Lepidium sativum L.). Compost extracts were obtained by shaking $10 \mathrm{~g}$ of compost fresh matter with $100 \mathrm{~cm}^{3}$ of distilled water for $2 \mathrm{~h}$ at room temperature.

In order to perform the germination index test, 10 seeds of cress were placed in Petri dishes (diameter $10 \mathrm{~cm}$ and depth $1.5 \mathrm{~cm}$ ) covered with blotting paper soaked with $5 \mathrm{~cm}^{3} \mathrm{~mL}$ compost extract and incubated for $48 \mathrm{~h}$ in the dark at $25^{\circ} \mathrm{C}$. The seed germination percentage and root elongation of the plants in $5 \mathrm{~cm}^{3} \mathrm{~mL}$ distilled water were also measured, and the sample was used as the control. A 5-mm primary root was considered as the operational definition of seed germination [23]. The percentages of relative seed germination (RSG), relative root growth (RRG), and germination index (GI) were calculated according to the following formula [24]:

$$
\begin{gathered}
\operatorname{RSG}(\%)=\frac{\text { mean number of seeds germinated in compost extract }}{\text { mean number of seeds germinated in control }} \cdot 100 \\
\operatorname{RRG}(\%)=\frac{\text { mean root lenght in compost extract }}{\text { mean root lenght in control }} \cdot 100
\end{gathered}
$$




$$
\mathrm{GI}(\%)=\frac{\mathrm{RSG} \cdot \mathrm{RRG}}{100}
$$

In order to determine the effect of composts on seed germination, a 3-day root growth Phytotoxkit test by Tigret ${ }^{\circledR}{ }^{\circledR}$ was used. The experiment was conducted under controlled conditions at $25^{\circ} \mathrm{C}$ in the dark. Ten seeds of plant were placed on plates covered with blotting paper with composts. After 3 days of the experiment, images of the plates were recorded using a camera, and next, the shoot length and root growth inhibition were determined using the ImageJ 1.8.0 graphic programme. The software and the calculation formula given below have been developed by Tigret ${ }^{\circledR}$ and form an integral part of the Phytotoxkit test.

Based on the collected data, the percentages of seed germination inhibition (SGI) and root growth inhibition (RGI) were calculated using the following formula:

$$
(\mathrm{SGI}) \text { or }(\mathrm{RGI})(\%)=\frac{\mathrm{A}-\mathrm{B}}{\mathrm{A}} \cdot 100
$$

where $A$ denotes the mean seed germination rate or root length in the control, and $B$ denotes the mean seed germination rate or root length on the compost extract.

\subsection{Statistical Analysis}

Analyses of samples were carried out in three replicates. The obtained results were subjected to formal evaluation with the assistance of one-way ANOVA. Each of the 19 parameters was tested independently using the F-test at the significance level $\alpha=0.95\left(\mathrm{~F}_{0.05}=2.39\right)$. The degrees of freedom for compared objects (composts) were $\mathrm{df}=9$, whereas the value of degrees of freedom for the error was $\mathrm{df}=20$. The calculated $\mathrm{F}$ statistic for the analysed parameters amounted to $\mathrm{F}_{\mathrm{OM}}=643.90$; $\mathrm{F}_{\mathrm{TOC}}=3166.55 ; \mathrm{F}_{\mathrm{CHS}}=4458.23 ; \mathrm{F}_{\mathrm{CHA}}=3571.10 ; \mathrm{F}_{\mathrm{CFA}}=1829.17 ; \mathrm{F}_{\mathrm{N}}=381.01 ; \mathrm{F}_{\mathrm{P}}=697.16 ; \mathrm{F}_{\mathrm{S}}=568.84 ;$ $\mathrm{F}_{\mathrm{Ca}}=69.36 ; \mathrm{F}_{\mathrm{Mg}}=31.65 ; \mathrm{F}_{\mathrm{K}}=131.25 ; \mathrm{F}_{\mathrm{Na}}=192.83 ; \mathrm{F}_{\mathrm{Fe}}=289.79 ; \mathrm{F}_{\mathrm{Ni}}=548.23 ; \mathrm{F}_{\mathrm{Zn}}=122.23 ; \mathrm{F}_{\mathrm{Mn}}=117.52 ;$ $\mathrm{F}_{\mathrm{Pb}}=54.16 ; \mathrm{F}_{\mathrm{Cr}}=76.14 ;$ and $\mathrm{F}_{\mathrm{Cu}}=304.88$.

The null hypothesis was tested that the average values of the examined parameter are equal for each of the 10 composts against the alternative hypothesis stating that not all averages are equal. As a result of the rejection of the null hypothesis, the least significant differences were calculated using the Tukey method at the significance level $\alpha=0.05$. Tukey's analysis was performed to distinguish homogeneous groups among the 10 composts (a mean comparison for which the $p$ value is $<0.05$ is considered different, and these differences were characterised using Tukey's honest significant difference test-HSD). These composts were included into homogeneous groups, for which the average contents of the tested parameter do not differ significantly. Homogeneous groups of composts are indicated by the same lowercase letters. The data were analysed using the STATOBL software working in the Windows environment.

\section{Results}

As shown by the obtained data, the tested composts differed in terms of their contents of macroand micronutrients, the quantity and quality of humus compounds, as well as the impact on the efficiency of seed germination and plant root growth. Among the 10 analysed composts, significant similarities and a lack of statistical differences can be observed between the analysed nutrient amounts. This is particularly evident in the case of composts 1 and 3, which had very similar values of C:N and $\mathrm{Q}_{4 / 6}$ (Table 2). Additionally, these composts did not differ in the contents of OM, $\mathrm{C}_{\mathrm{HS}}$, the amounts of $\mathrm{Mg}, \mathrm{S}, \mathrm{P}, \mathrm{Fe}, \mathrm{Zn}$, and $\mathrm{Cu}$ (Figures 1 and 2, Tables 3 and 4). Also the values of SGI, RGI, and GI were comparable for mentioned composts (Figures 3 and 4). In addition, composts 7 and 8 were characterised by contents of most of the analysed nutrients as well as TOC, OM, and $\mathrm{C}_{\mathrm{FA}}$, which were not statistically different. Composts 2 and 4 did not differ in terms of OM, N, S, P, Mg, Ca, Fe, Zn, and Cr contents (Tables 3 and 4, Figure 1). These composts also presented similar values of $\mathrm{Q}_{4 / 6}, \mathrm{SGI}, \mathrm{RGI}$, and GI (Table 2, Figures 3 and 4). Despite the fact that composts 5 and 6 were prepared in the same 
technology using sewage sludge (although in different percentage shares, see: Table 1), they showed no significant differences only in the contents of TOC, OM, $\mathrm{C}_{\mathrm{HA}}, \mathrm{C}_{\mathrm{HS}}$, and $\mathrm{N}$ (Figures 1 and 2, Table 3). Additionally, HI (18.8-20.1\%), HR (27.5-29.0\%) and DP (2.2-2.4) values were comparable for these composts (Table 2). Similar effects on seed germination and root growth were found for composts 9 and 10 (Figure 4).

Table 2. The C:N ratio and humification indexes obtained for analysed composts. DP: degree of polymerisation, HI: humification index, HR: humification ratio.

\begin{tabular}{cccccc}
\hline Compost & HI (\%) & HR (\%) & DP $\left(\mathbf{C}_{\mathbf{H A}}: \mathbf{C}_{\mathbf{F A}}\right.$ Ratio $)$ & $\mathbf{Q}_{4 / 6}$ & C:N \\
\hline C1 & 9.3 & 17.6 & 1.1 & 7.2 & $12: 1$ \\
C2 & 13.2 & 18.6 & 2.4 & 7.4 & $9: 1$ \\
C3 & 3.5 & 13.5 & 0.4 & 7.1 & $16: 1$ \\
C4 & 7.0 & 17.4 & 0.7 & 7.8 & $8: 1$ \\
C5 & 18.8 & 27.5 & 2.2 & 9.2 & $17: 1$ \\
C6 & 20.1 & 29.0 & 2.4 & 17.3 & $9: 1$ \\
C7 & 13.7 & 20.3 & 2.1 & 6.2 & $11: 1$ \\
C8 & 17.3 & 23.5 & 2.8 & 5.8 & $12: 1$ \\
C9 & 5.0 & 11.5 & 0.8 & 7.5 & $12: 1$ \\
C10 & 25.2 & 37.8 & 2.4 & 6.4 & $5: 1$ \\
\hline
\end{tabular}

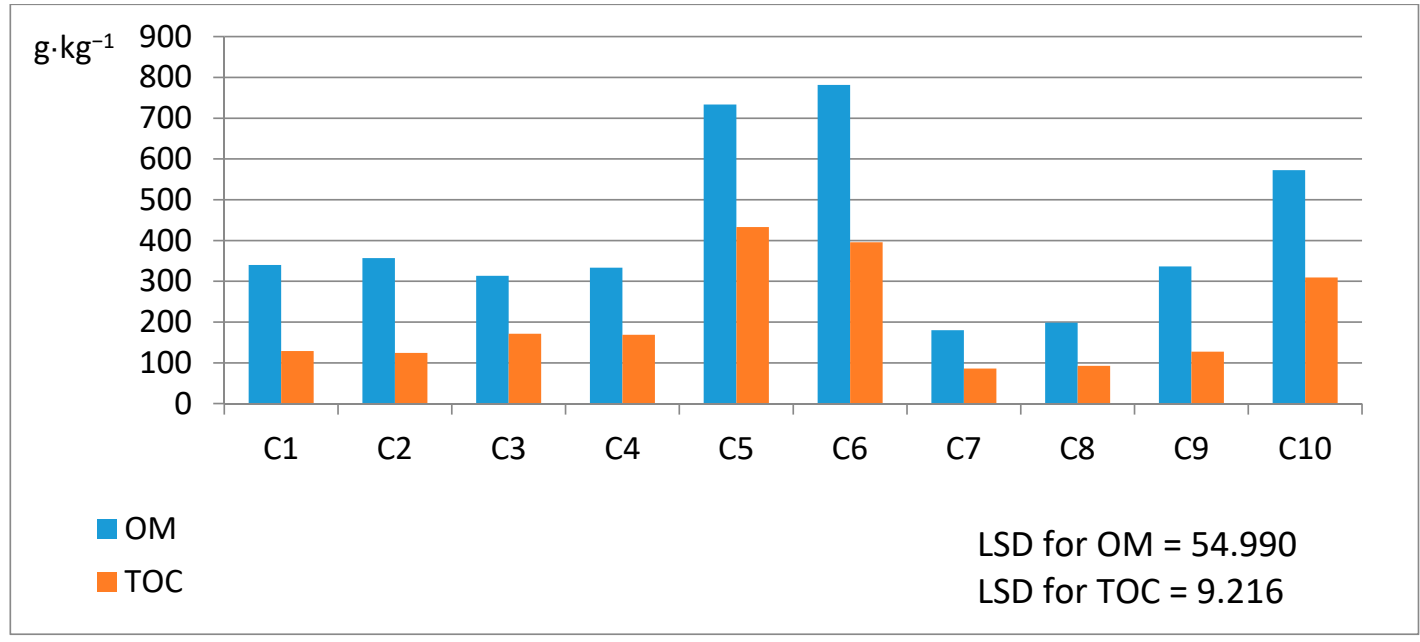

Figure 1. Contents of organic matter and total organic carbon in analysed composts.

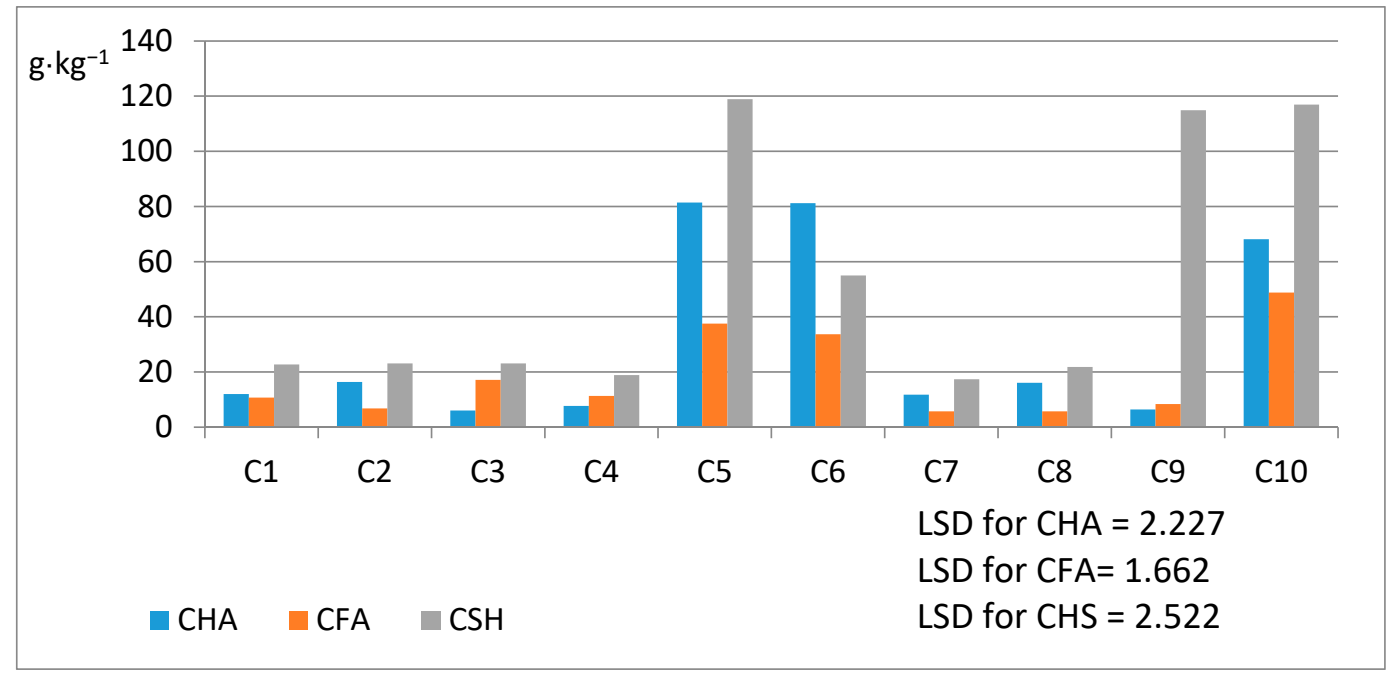

Figure 2. Contents of $\mathrm{C}_{\mathrm{HS}}, \mathrm{C}_{\mathrm{HA}}$, and $\mathrm{C}_{\mathrm{FA}}$ in analysed composts. 
Table 3. Macronutrient contents in analysed composts $\left(\mathrm{g} \cdot \mathrm{kg}^{-1}\right)$.

\begin{tabular}{cccccccc}
\hline Compost & $\mathbf{N}$ & $\mathbf{P}$ & $\mathbf{K}$ & $\mathbf{S}$ & $\mathbf{C a}$ & $\mathbf{M g}$ & $\mathbf{N a}$ \\
\hline $\mathrm{C} 1$ & $15.8 \mathrm{c}$ & $2.8 \mathrm{~d}$ & $6.6 \mathrm{c}$ & $0.8 \mathrm{ef}$ & $18.8 \mathrm{ab}$ & $2.6 \mathrm{ab}$ & $0.9 \mathrm{~b}$ \\
$\mathrm{C} 2$ & $13.8 \mathrm{~d}$ & $2.7 \mathrm{~d}$ & $7.4 \mathrm{~b}$ & $1.3 \mathrm{~cd}$ & $16.3 \mathrm{bc}$ & $2.3 \mathrm{~b}$ & $0.6 \mathrm{~d}$ \\
$\mathrm{C} 3$ & $10.5 \mathrm{e}$ & $2.7 \mathrm{~d}$ & $5.3 \mathrm{~d}$ & $0.7 \mathrm{ef}$ & $14.1 \mathrm{~cd}$ & $2.3 \mathrm{~b}$ & $0.7 \mathrm{c}$ \\
$\mathrm{C} 4$ & $13.3 \mathrm{~d}$ & $2.6 \mathrm{~d}$ & $5.7 \mathrm{~d}$ & $1.0 \mathrm{de}$ & $15.9 \mathrm{bc}$ & $2.7 \mathrm{ab}$ & $0.5 \mathrm{e}$ \\
$\mathrm{C} 5$ & $25.0 \mathrm{a}$ & $4.8 \mathrm{a}$ & $9.9 \mathrm{a}$ & $1.8 \mathrm{~b}$ & $18.9 \mathrm{ab}$ & $2.9 \mathrm{a}$ & $0.9 \mathrm{~b}$ \\
$\mathrm{C} 6$ & $24.3 \mathrm{a}$ & $2.4 \mathrm{~b}$ & $2.9 \mathrm{f}$ & $0.8 \mathrm{ef}$ & $6.4 \mathrm{e}$ & $1.2 \mathrm{c}$ & $0.6 \mathrm{de}$ \\
$\mathrm{C} 7$ & $3.2 \mathrm{~g}$ & $1.5 \mathrm{f}$ & $3.0 \mathrm{f}$ & $0.2 \mathrm{gh}$ & $6.9 \mathrm{e}$ & $1.3 \mathrm{c}$ & $0.3 \mathrm{f}$ \\
$\mathrm{C} 8$ & $7.5 \mathrm{f}$ & $2.4 \mathrm{e}$ & $2.9 \mathrm{f}$ & $0.5 \mathrm{fg}$ & $7.6 \mathrm{e}$ & $1.1 \mathrm{c}$ & $0.2 \mathrm{f}$ \\
$\mathrm{C} 9$ & $10.8 \mathrm{e}$ & $1.8 \mathrm{f}$ & $4.7 \mathrm{e}$ & $1.6 \mathrm{bc}$ & $21.4 \mathrm{a}$ & $2.9 \mathrm{a}$ & $0.8 \mathrm{c}$ \\
$\mathrm{C} 10$ & $23.6 \mathrm{~b}$ & $4.2 \mathrm{c}$ & $4.3 \mathrm{e}$ & $6.2 \mathrm{a}$ & $11.9 \mathrm{~d}$ & $1.4 \mathrm{c}$ & $1.4 \mathrm{a}$ \\
\hline
\end{tabular}

Significant differences between the means are marked with different letters.

Table 4. Micronutrient contents in analysed composts $\left(\mathrm{mg} \cdot \mathrm{kg}^{-1}\right)$.

\begin{tabular}{cccccc}
\hline Compost & Fe & Zn & $\mathbf{C u}$ & $\mathbf{M n}$ & $\mathbf{N i}$ \\
\hline C1 & $4246.7 \mathrm{de}$ & $185.3 \mathrm{~d}$ & $37.3 \mathrm{ef}$ & $191.0 \mathrm{~cd}$ & $4.6 \mathrm{f}$ \\
C2 & $4720.0 \mathrm{~d}$ & $188.0 \mathrm{~d}$ & $27.9 \mathrm{cde}$ & $137.4 \mathrm{f}$ & $6.7 \mathrm{e}$ \\
C3 & $5086.7 \mathrm{~d}$ & $179,1 \mathrm{~d}$ & $33.3 \mathrm{def}$ & $156.1 \mathrm{e}$ & $6.6 \mathrm{e}$ \\
C4 & $4666.7 \mathrm{~d}$ & $174.5 \mathrm{~d}$ & $21.4 \mathrm{f}$ & $183.1 \mathrm{cde}$ & $7.7 \mathrm{de}$ \\
C5 & $19316.7 \mathrm{a}$ & $497.1 \mathrm{a}$ & $153.7 \mathrm{a}$ & $283.0 \mathrm{~b}$ & $33.0 \mathrm{a}$ \\
C6 & $8420.0 \mathrm{~b}$ & $372.4 \mathrm{~b}$ & $118.4 \mathrm{~b}$ & $195.3 \mathrm{~cd}$ & $21.5 \mathrm{~b}$ \\
C7 & $4220.0 \mathrm{de}$ & $45.8 \mathrm{f}$ & $7.3 \mathrm{gh}$ & $196.2 \mathrm{~cd}$ & $3.4 \mathrm{f}$ \\
C8 & $3843.3 \mathrm{de}$ & $80.6 \mathrm{e}$ & $24.8 \mathrm{f}$ & $210.6 \mathrm{c}$ & $4.6 \mathrm{f}$ \\
C9 & $6520.0 \mathrm{c}$ & $322.4 \mathrm{~b}$ & $42.7 \mathrm{~cd}$ & $188.8 \mathrm{cde}$ & $10.4 \mathrm{c}$ \\
C10 & $3250.0 \mathrm{e}$ & $272.7 \mathrm{c}$ & $47.3 \mathrm{c}$ & $389.8 \mathrm{a}$ & $8.8 \mathrm{~cd}$ \\
\hline
\end{tabular}

Significant differences between the means are marked with different letters.

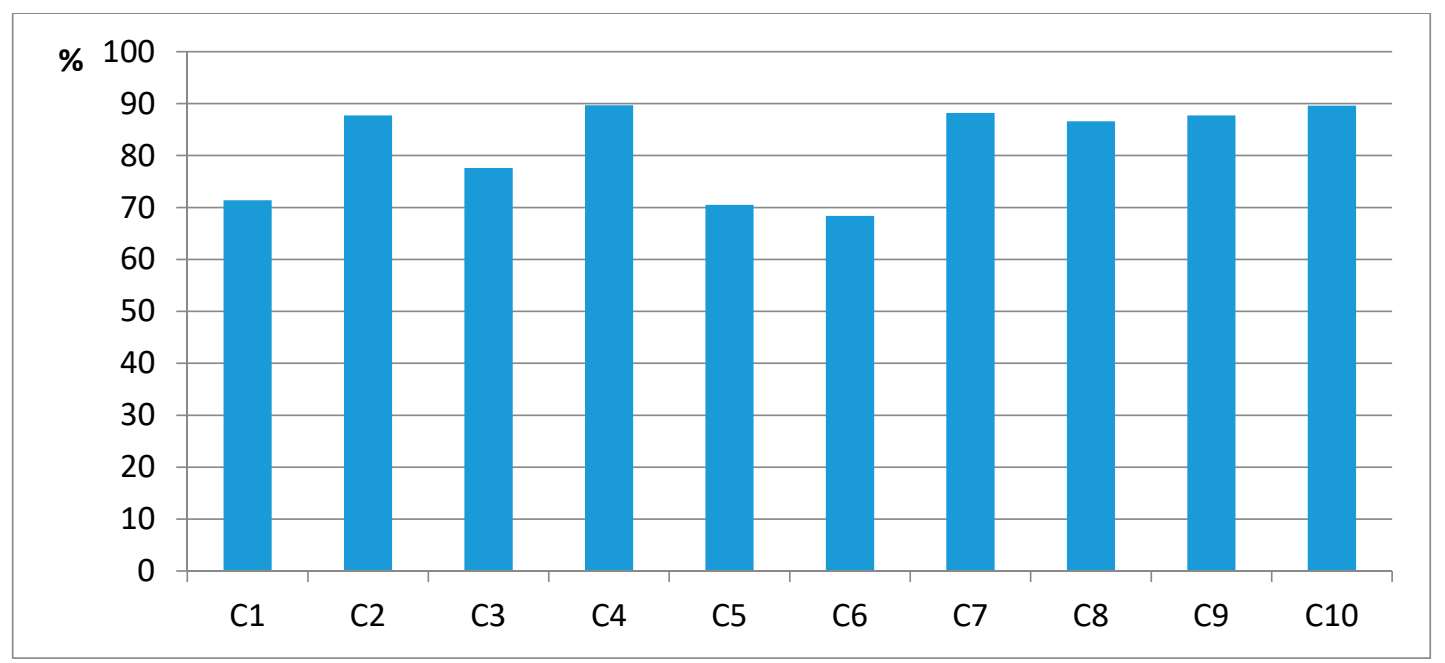

Figure 3. Germination index values for analysed composts. 


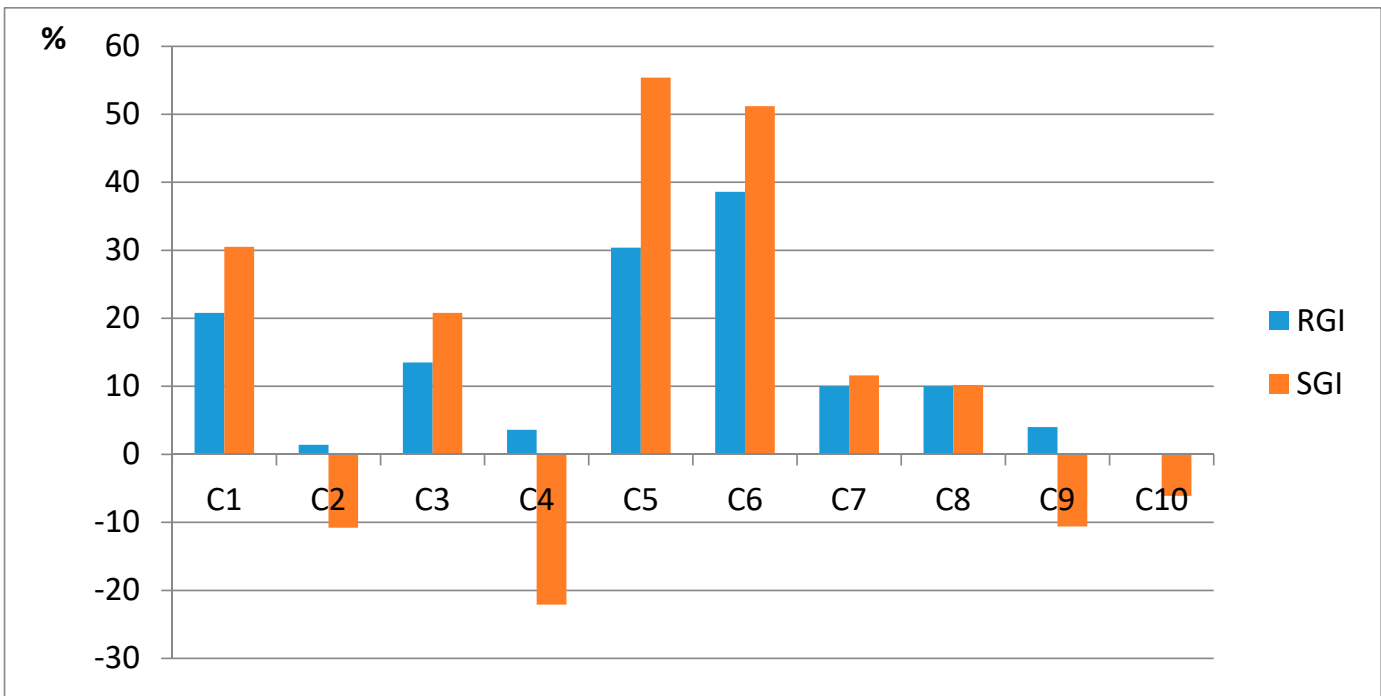

Figure 4. RGI and SGI values for analysed composts.

According to the Polish standards specified in the Regulation of the Minister of Agriculture and Rural Development [25], organic fertilisers have to contain a minimum of $30 \%$ organic matter, while contents of nitrogen $(\mathrm{N})$, phosphorus $\left(\mathrm{P}_{2} \mathrm{O}_{5}\right)$, and potassium $\left(\mathrm{K}_{2} \mathrm{O}\right)$ have to have a minimum of $0.3 \%, 0.2 \%$, and $0.2 \%$, respectively. Referring to the above values, only composts 7 and 8 did not meet the criterion for the minimum amount of organic matter (Figure 1). The amounts of $\mathrm{N}$ ranged from $0.3 \%$ (C7) to $2.5 \%$ (C5), thus meeting the required minimum. In addition, all the composts met the threshold for potassium contents, because the $\mathrm{K}$ level converted into $\mathrm{K}_{2} \mathrm{O}$ ranged from $0.2 \%$ (C8) to $1.2 \%$ (C5). Phosphorus expressed as $\mathrm{P}_{2} \mathrm{O}_{5}$ amounts ranged from $0.3 \%$ (C7) to $1 \%$ (C5 and C6), thus meeting the threshold specified in the legal act. The requirements given in the Regulation of the Minister of Agriculture and Rural Development [25] describing the limits of heavy metals in organic fertilisers are more lenient compared with those contained in the EC 889/2008 Commission Regulation [26], because Polish law specifies that the levels of the following heavy metals in $\mathrm{mg} \cdot \mathrm{kg}^{-1}$ of dry matter of compost cannot exceed the following thresholds: $\mathrm{Cr}=100 ; \mathrm{Cd}=5 ; \mathrm{Ni}=60 ; \mathrm{Pb}=140$; and $\mathrm{Hg}=2$. However, the EU law in composted or fermented household wastes allows only the presence of $\mathrm{Cr}=70$; $\mathrm{Ni}=25 ; \mathrm{Pb}=45 ; \mathrm{Cd}=70 ; \mathrm{Cu}=70 ; \mathrm{Zn}=200$ and $\mathrm{Hg}=0.4 \mathrm{mg} \cdot \mathrm{kg}^{-1}$. Comparing the above-mentioned threshold values with those obtained for the analysed composts, it should be stated that both Polish and European standards were met for composts prepared by the AANC technology (C7 and C8). The other composts exceeded the given limit values. For $\mathrm{Cu}$, it was found for $\mathrm{C} 5\left(153.7 \mathrm{mg} \cdot \mathrm{kg}^{-1}\right)$ and C6 (118.4 $\left.\mathrm{mg}^{-\mathrm{kg}^{-1}}\right)$. The amounts of $\mathrm{Zn}$ did not meet the criteria and were higher in the case of C5 (497.2 $\left.\mathrm{mg} \cdot \mathrm{kg}^{-1}\right)$, C6 (372.4 $\left.\mathrm{mg} \cdot \mathrm{kg}^{-1}\right)$, C9 $\left(322.4 \mathrm{mg} \cdot \mathrm{kg}^{-1}\right)$ and C10 $\left(272.7 \mathrm{mg} \cdot \mathrm{kg}^{-1}\right)$. Compost 5 with $33 \mathrm{mg} \cdot \mathrm{kg}^{-1}$ exceeded the limit for Ni. As it results from the above, compost 5 was characterised not only by the highest contents of macronutrients (TOC, N, P, K), but also microelements ( $\mathrm{Zn}, \mathrm{Cu}, \mathrm{Ni}, \mathrm{Fe}$ ) (Tables 3 and 4) and heavy metals $(\mathrm{Cr}, \mathrm{Pb})$ (Figure 5). The greatest contents of $\mathrm{HS}$ and $\mathrm{C}_{\mathrm{HA}}$ (Figure 2) as well as one of the highest values of $\mathrm{HI}(18.8 \%)$ and HR (27.5\%), were also obtained for this compost (Table 2).

It should be emphasised that C5, similarly to C6, very strongly inhibited seed germination (SGI = $30.4-38.6 \%)$ and plant root growth $(\mathrm{RGI}=51.2-55.7 \%)$. This corresponded to the lowest germination index (GI) values from $68.4 \%$ to $70.5 \%$ (Figure 3 ).

The highest amounts of $\mathrm{Na}\left(1.4 \mathrm{~g} \cdot \mathrm{kg}^{-1}\right), \mathrm{S}\left(6.2 \mathrm{~g} \cdot \mathrm{kg}^{-1}\right), \mathrm{Mn}\left(389.8 \mathrm{mg} \cdot \mathrm{kg}^{-1}\right)$, and $\mathrm{C}_{\mathrm{FA}}\left(48.8 \mathrm{~g} \cdot \mathrm{kg}^{-1}\right)$ were recorded for $\mathrm{C} 10$ (Tables 3 and 4; Figure 2), while C9 was the most abundant in $\mathrm{Ca}\left(21.4 \mathrm{~g} \cdot \mathrm{kg}^{-1}\right)$ and $\mathrm{Mg}\left(2.9 \mathrm{mg} \cdot \mathrm{kg}^{-1}\right)$ (Table 3). Among all the analysed composts, $\mathrm{C} 7 \mathrm{had}$ the worst fertilising properties because of the smallest amounts of OM $\left(180 \mathrm{~g} \cdot \mathrm{kg}^{-1}\right), \mathrm{N}\left(3.2 \mathrm{~g} \cdot \mathrm{kg}^{-1}\right), \mathrm{C}\left(85.8 \mathrm{~g} \cdot \mathrm{kg}^{-1}\right), \mathrm{C}_{\mathrm{HS}}\left(17.4 \mathrm{~g} \cdot \mathrm{kg}^{-1}\right)$, $\mathrm{C}_{\mathrm{FA}}\left(5.65 \mathrm{~g} \cdot \mathrm{kg}^{-1}\right), \mathrm{P}\left(1.5 \mathrm{~g} \cdot \mathrm{kg}^{-1}\right), \mathrm{S}\left(0.3 \mathrm{~g} \cdot \mathrm{kg}^{-1}\right), \mathrm{Ca}\left(6.9 \mathrm{~g} \cdot \mathrm{kg}^{-1}\right), \mathrm{Ni}\left(3.4 \mathrm{mg} \cdot \mathrm{kg}^{-1}\right), \mathrm{Zn}\left(45.8 \mathrm{mg} \cdot \mathrm{kg}^{-1}\right)$, and $\mathrm{Cu}\left(7.3 \mathrm{mg} \cdot \mathrm{kg}^{-1}\right)$ (Tables 3 and 4; Figures 1 and 2). At the same time, $\mathrm{C} 7$ was the least loaded 
with heavy metals, $\mathrm{Cr}\left(4.0 \mathrm{~g} \cdot \mathrm{kg}^{-1}\right)$ and $\mathrm{Pb}\left(14.3 \mathrm{~g} \cdot \mathrm{kg}^{-1}\right)$, which needs to be considered as beneficial (Figure 5).

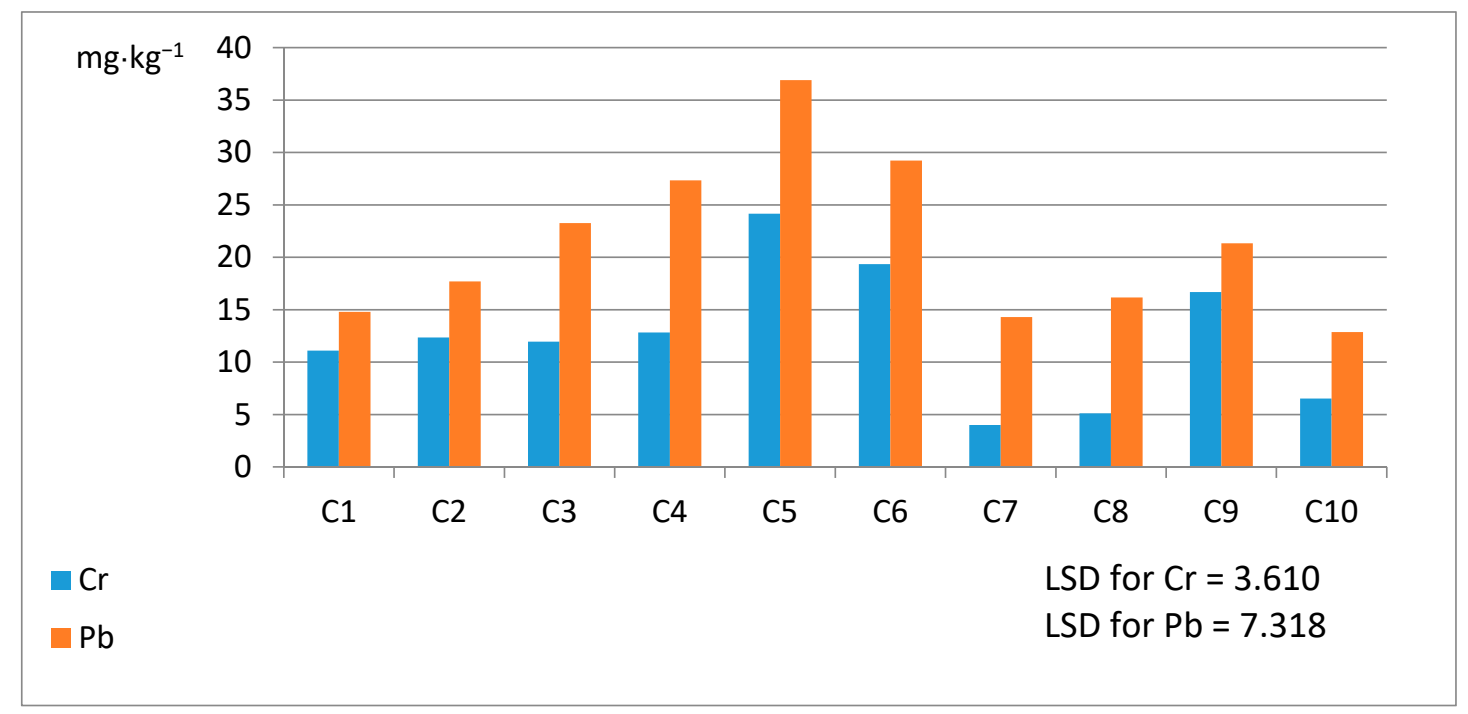

Figure 5. Heavy metal contents in analysed composts.

Due to the same composting method (AANC) applied and the used biowastes, a considerable similarity was observed between $\mathrm{C} 7$ and $\mathrm{C} 8$, as they did not differ significantly in their contents of $\mathrm{OM}$, TOC, $\mathrm{CFA}_{\mathrm{FA}}, \mathrm{K}, \mathrm{Ca}, \mathrm{Mg}, \mathrm{Na}, \mathrm{Fe}, \mathrm{Mn}, \mathrm{Ni}, \mathrm{Pb}$, and $\mathrm{Cr}$ (Tables 3 and 4; Figures 1, 2 and 5). These composts also had comparable values of HI (13.7-17.3\%), HR (20.3-23.5\%), and DP (2.1-2.8) (Table 2). Additionally, both composts had the same positive effect on seed germination and root growth, which was manifested in low SGI inhibition (10\%) as well as RGI inhibition (10.2-11.6\%). At the same time, a large percentage $(88.2-86.6 \%)$ of GI was found to be related to this factor (Figures 3 and 4).

When referring to the phytotoxic effects of the tested composts, the least harmful effects of $\mathrm{C} 2$, C4, C9, and C10 should be emphasised. These composts inhibited the germination of seeds within a very low range (from 0 to $4 \%$ ), which was similar to the values for root growth (from $-22.1 \%$ to $-6.1 \%$ ), while simultaneously the highest values of the GI index (from 87.7 to $89.6 \%$ ) were determined (Figures 3 and 4). Despite the fact that the above-mentioned composts induced plant growth and development in a similar way, they differed in terms of their abundance in macro- and micronutrients, as well as the quality and quantity of humic compounds. As it results from the data in Tables 3 and 4 and Figure 2, composts 9 and 10 generally were characterised by higher contents of nutrients in relation to the levels found in composts 2 and 4. Particularly noteworthy is the large content of $S\left(6.2 \mathrm{~g} \cdot \mathrm{kg}^{-1}\right)$, $\mathrm{Na}\left(1.4 \mathrm{~g} \cdot \mathrm{kg}^{-1}\right), \mathrm{Mn}\left(389.8 \mathrm{~g} \cdot \mathrm{kg}^{-1}\right)$ and $\mathrm{C}_{\mathrm{FA}}\left(48.8 \mathrm{~g} \cdot \mathrm{kg}^{-1}\right)$ in $\mathrm{C} 10$. The highest values of $\mathrm{HI}(25.2 \%)$ and HR $(37.8 \%)$ calculated for this compost need to be stressed in this respect (Table 2).

\section{Discussion}

Obviously, first of all the composted wastes before application must meet the criteria of environmental safety imposed by legal regulations. The analysed composts met the Polish quality criteria except for two composts (C7 and C8), which had an organic matter content below the required $30 \%$. These composts were prepared using the AANC method and prepared mainly from food scraps from kitchen and yard trimmings as plant residues, i.e., raw materials relatively poor in non-degradable or sparsely degradable organic compounds with a strongly polymerised structure, which would create humified organic matter. The above-ground parts of plants and food residues have a high decomposition rate, which does not promote organic matter accumulation. On the other hand, composts 5, 6, 9, and 10 did not meet the stringent European requirements regarding $\mathrm{Zn}$ and $\mathrm{Ni}$ contents (only for $\mathrm{C} 5$ ). The above information testifies to the chemical diversity of the composts 
proved in this study, which is primarily due to the use of sewage sludge, wastes rich in organic matter as well as macro- and micronutrients [27], and to a lesser extent the impact of the composting methods used. A number of papers on the subject of compost application [10,21,28-30] present different levels of both macro- and micronutrients, which is related to various and different composted wastes. Therefore, it is difficult to compare the data obtained in this study with those presented in the literature. Nevertheless, generally, it may be concluded that composts prepared on the basis of selected biowastes are characterised by low nutrient and organic matter contents, as evidenced by the results of analyses for composts 7 and 8 . On the other hand, composts prepared based on biowastes and biodegradable waste (sewage sludge), such as composts 5 and 6, presented the largest contents of most nutrients and organic matter. The obtained data clearly indicate that there is a strong relationship between the chemical diversity of the used waste and compost abundance in nutrients and organic matter.

A separate but extremely important issue when assessing the quality of composts is not only their chemical composition, but also the degree of stability and maturity. Achieving compost stability and maturity is an extremely important element of composting, because an unstable and immature organic material may have adverse effects on plant growth and the environment. First of all, the presence of volatile chemicals, such as organic acids toxic for plants, must be underlined. Additionally, an incompletely matured compost with a higher $\mathrm{C}: \mathrm{N}$ ratio can lead to a biological block of nitrogen, which is also known as "nitrogen starvation" [31]. Therefore, before applying compost, it is necessary to assess its degree of maturity and stability. As given in Table 1, the used composting techniques were the same in most cases, similarly as the maturing time of the composted mixture. The traditional and easier approach to evaluate compost maturity is to use the C:N value. The application of the C:N ratio as an indicator of compost maturity is widely discussed in the literature [31]. The C:N ratio is a function of TOC and N, which changes during the composting process in organic materials, and thanks to this, it is considered a useful tool in the evaluation of compost maturity. It is widely recognised that the progress of carbon and nitrogen mineralisation is strictly related. As the decomposition progresses due to the losses of $\mathrm{C}$, the $\mathrm{C}$ content of compostable material decreases, and with time, the $\mathrm{N}$ content increases, which results in the variable $\mathrm{C}: \mathrm{N}$ ratio at the end of the composting process being lower than at the beginning. Unfortunately, the $\mathrm{C}: \mathrm{N}$ ratio considerably varies in raw materials, and as a result, this could be a less reliable parameter; thus, it often gives a misleading indication of maturity, and it may also fail to indicate a material that is sufficiently decomposed. According to different opinions concerning the usefulness of the C: $\mathrm{N}$ value in compost maturity assessment, there is no unified, standardised limit value of this parameter. Azim et al. [31] reviewed the literature data in terms of specific $\mathrm{C}: \mathrm{N}$ ratio thresholds for maturity compost assessment. The range of values cited by these authors was broad, ranging from 7.8 to 20.5, with an average at approximately 12 . Antil et al. [32] indicated a value between 15 and 20 as satisfactory. In addition, Asquer et al. [33] stated that values of C:N lower than 20 are considered an indicator of sufficient $\mathrm{N}$ supply for plant growth. At the same time, Bernal et al. [34] stated that a C:N ratio lower than 12 indicates a good degree of compost maturity. According to Gomez-Brandon et al. [35] and Singh et al. [36], the C:N ratio within the range of 10-15 shows a stable, mature material. Taking under consideration a broad ratio of C:N of 10-20:1 as the criterion, only analysed composts $2,4,6$, and 10 failed to meet this criterion (Table 2).

Knowing that the humified fraction of organic compounds is the most important and responsible for fertility and quality of humic compounds, the evaluation of humification parameters of composts is essential. Since maturation also implies the formation of some humic-like substance, the degree of organic matter humification is generally accepted as a criterion of maturity and HI, HR, and DP are usually applied. It is assumed that mature composts should have an HI value above $30 \%$ [37]. For such a criterion being adopted here, none of the composts tested reached such a value, because as indicated in Table 2, they ranged from $3.5 \%$ (C3) to $25.2 \%$ (C10). In turn, the HR values ranged from $11.5 \%$ (C9) to $37.8 \%$ (C10). There is no limit HR value specified in the literature, which could be helpful in assessing the compost maturity. Thus, it makes it difficult to evaluate the obtained results in this study. Nevertheless, outcomes presented by Bustamante et al. [28] or Asquer et al. [33] indicated 
comparable values of HR and HI. Alvarenga et al. [38] stressed the considerable variation between individual composts in terms of respective $\mathrm{HR}$ and $\mathrm{HI}$ values.

The $\mathrm{C}_{\mathrm{HA}}: \mathrm{C}_{\mathrm{FA}}$ ratio is widely used to describe the relative speed of $\mathrm{HA}$ and FA transformation, as well as the maturity of compost. Iglesias-Jimez and Pérez-García [39] stated that a value of the $\mathrm{C}_{\mathrm{HA}}: \mathrm{C}_{\mathrm{FA}}$ ratio higher than 1.9 indicates compost maturity. In turn, Azim et al. [31] on the basis of a literature review, stated that the correct threshold value of the polymerisation degree needs to be greater than 1 . On the other hand, Alavarenga et al. [38] considered the limit value of 2.5 for the $\mathrm{C}_{\mathrm{HA}} \mathrm{C}_{\mathrm{FA}}$ ratio. Taking into account that threshold, it may be assumed that only composts 2, 5, 6, 7, 8, and 10 were well matured, because the values obtained for them ranged from 2.1 to 2.8 (Table 2). Optical density expressed as $\mathrm{Q}_{4 / 6}$ ranging from 3.23 to 8.8 indicated a successful maturation of composts [40]. This threshold was met by most of the composts except for C5 (9.2) and C6 (17.3) (Table 2).

The stability of composts is commonly evaluated using biological methods, such as e.g., the germination index $[17,21,29,41,42]$. The application of biotests is considered to be a sophisticated method to evaluate environmental pollution, supplementing chemical methods. The data given in the literature on the limited threshold of GI describing the maturity of composts are inconsistent. In relation to the obtained results, Antil et al. [32] proposed GI > 70\% as a threshold value, which may be accepted as an indication for compost maturity. According to Sangamithirai et al. [43], a phytotoxin-free and mature compost is characterised by a GI value of more than $80 \%$. In addition, Jakubus and Bakinowska [41] indicated reliability in compost evaluation using a GI threshold over $80 \%$. On the other hand, Komilis and Tziouvaras [44] stated that a GI value greater than $100 \%$ indicates a beneficial effect on seed growth and therefore identifies a mature compost, whereas Ko et al. [45] reported that compost having a GI value $>110 \%$ was considered mature. Referring to the most frequently quoted $80 \%$ GI value, composts numbered 2, 4, 7, 8, 9, and 10 met these criteria.

Despite the opinion on GI being rapid and sensitive, it has also been subjected to criticism, because it is a tedious bioassay to perform, as it requires about $48-72 \mathrm{~h}$ to run and involves complicated operations, while the sensitivity of plant species to phytotoxic chemicals in compost may vary. Unfortunately, data obtained on the basis of that biological assay are neither comparable nor standardised. Therefore, in the present study, apart from the popular GI, also a 3-day Phytotoxkit test was applied. This bioassay meets the requirement of the ISO standard and evaluates the rate of inhibition for seed germination and root growth. The results of this test were consistent with the previously presented finding of GI recorded for the above-mentioned composts and confirmed their lowest degree of inhibition for seed germination and root growth. The application of the Phytotoxkit test to evaluate the quality of composts prepared from various organic waste should be considered as an innovative approach to the issues raised. The obtained data showed its considerable usefulness, indicating that it can be a valuable supplementation of other methods.

The lack of harmonised standards and threshold values for individual indexes makes it difficult to interpret the analysed composts in terms of their maturity and stability. The results of the research carried out clearly revealed these imperfections, indicating at the same time the advisability of further research in order to develop common and uniform criteria for assessing the quality of composts prepared from various organic wastes. Especially based on the above data, it may be concluded that compost maturity was assessed differently depending on the applied index. From among the examined group of composts, the maturity of the following composts was most often assessed positively: 2, 3, $5,6,7$ and 8. With regard to compost stability assessed by the bioassay, composts 2, 4, 7, 8, 9 and 10 showed the lowest phytotoxic effect.

\section{Conclusions}

As confirmed by statistical analysis, the differences in the chemical composition of composts primarily resulted from the use of raw material for composting, and to a lesser extent from the process technology used. Despite the fact that composts prepared with biowastes using the AANC method (C7 and C8) were evaluated as fertilisers with low abundance in nutrients and organic matter, 
they were characterised by favourable stability and maturity parameters. Similarly, the opinion concerning the quality of composts could be related to the composts being a mixture of biodegradable wastes and biowastes collected separately by the inhabitants of a medium-sized town (C2) and a mixture of biowastes and manure in a 1:1 ratio (C9). The above-mentioned composts 2 and 9 were characterised by a slightly higher abundance in nutrients and organic matter in relation to composts 7 and 8 . As a result, these types of fertilisers may be recommended for small-scale vegetable cultivation, ornamental gardens, or the maintenance of urban greenery, where cultivated plants do not have such high nutritional requirements. Taking into account the high contents of nutrients and organic matter and the satisfactory quality of humic compounds, composts prepared with a share of sewage sludge (C5 and C6) are worth recommending as organic fertilisers used for reclamation of post-industrial areas, where the soil production capacity should be rebuilt in the first stage. Due to the strongest phytotoxic effect of this type of compost, it should not be proposed for horticultural and agricultural crops.

Referring to the indexes evaluating maturity and stability of organic fertilisers applied in the presented studies, it should be stated that there are no uniform critical values that can be applied to compost assessment in a reliable and universal manner. Especially the very popular indicator such as the C:N ratio should be interpreted as not fully descriptive of the compost maturity index, while more reliable parameters such as DP should be taken under consideration for compost evaluation. Based on the results of the author's research for evaluation of composts, the bioassay may be recommended, as well as the degree of polymerisation of humic compounds expressed by the $\mathrm{DP}\left(\mathrm{C}_{\mathrm{HA}}: \mathrm{C}_{\mathrm{FA}}\right.$ ratio $)$ index.

Summing up, composts as organic fertilisers were found to be a valuable source of nutrients and organic matter. From the economic aspect, it should be underlined that raw materials used for composting are easily available locally, and thus the final product is relatively cheap and marketable for gardeners or farmers in comparison to expensive mineral fertilisers. In addition, local authorities responsible for managing organic waste should opt for this form of their recycling, increasing the attractiveness and popularity of this type of fertiliser.

Funding: The publication was co-financed within the framework of Ministry of Science and Higher Education programme as "Regional Initiative Excellence" in years 2019-2022, Project No. 005/RID/2018/19".

Conflicts of Interest: No potential conflict of interest was reported by the author.

\section{References}

1. Chen, D.M.-C.; Bodirsky, B.L.; Krueger, T.; Mishra, A.; Popp, A. The world's growing municipal solid waste: Trends and impacts. Environ. Res. Lett. 2020. [CrossRef]

2. Sharma, B.; Sarkar, A.; Singh, P.; Singh, R.P. Agricultural utilisation of biosolids: A review on potential effects on soil and plant grown. Waste Manag. 2017, 64, 117-132. [CrossRef] [PubMed]

3. Communication from the Commission to the European Parliament, the Council, the European Economic and Social Committee and the Committee of the Region. Toward A Circular Economy: Zero Waste Programme for Europe. COM (2014) 398 Final. Available online: https:/eur-lex.europa.eu/resource.html?uri=cellar: aa88c66d-4553-11e4-a0cb-01aa75ed71a1.0022.03/DOC_1\&format=PDF (accessed on 2 May 2020).

4. Central Statistical Office. Environment Protection, Warszawa 2019. Available online: https://stat.gov.pl/obszarytematyczne/srodowisko-energia/srodowisko/ochrona-srodowiska-2019,1,20.html (accessed on 2 May 2020).

5. Council Directive 1999/31/EC of 26 April 1999 on the landfill of waste. Available online: https://eur-lex. europa.eu/legal-content/EN/TXT/PDF/?uri=CELEX:31999L0031\&from=EN (accessed on 2 May 2020).

6. Bio-waste in Europe. Available online: https://www.google.com/search?client=firefox-b-d\&q=biowaste+management+ in+Europe\&spell=1\&sa=X\&ved=2ahUKEwjCgOynjK7oAhVBw8QBHQopAToQBSgAegQIDBAp\&biw=1054\& bih=582 (accessed on 2 May 2020).

7. Ordinance of the Economy and Labor Minister on criteria and procedures for admission of waste to storage in a type of waste. J. Laws 2013. item 38.

8. Gu, W.; Zhang, F.; Xu, P.; Tang, S.; Xie, K.; Huang, X.; Huang, Q. Effects of sulphur and Thiobacillus thioparus on cow manure aerobic composting. Bioresour. Technol. 2011, 102, 6520-6529. [CrossRef] [PubMed] 
9. Deepesh, V.; Kumar, V.; Suma, K.; Ajay, S.; Gnanavelu, A.; Madhusudanan, M. Evaluation of an organic soil amendment generated from municipal solid waste seeded with activated sewage sludge. J. Mater Cycles Waste Manag. 2016, 18, 273-286. [CrossRef]

10. Thomas, C.L.; Acquah, G.E.; Whitmore, A.P.; McGrath, S.P.; Haefele, S.M. The effect of different organic fertilizer on yield and soil and crop nutrient concentrations. Agronomy 2019, 9, 776. [CrossRef]

11. Alvarenga, P.; Mourinha, C.; Farto, M.; Santos, T.; Palma, P.; Sengo, J.; Morais, M.C.; Cunha-Queda, C. Sewage sludge, compost and other representative organic wastes as agricultural soil amendments: Benefits versus limiting factors. Waste Manag. 2015, 40, 44-52. [CrossRef]

12. Jakubus, M.; Bakinowska, E.; Gałka, B. The quantitative changes of nutrients in two contrasting soils amended with sewage sludge compost evaluated by various statistical tools. Acta Agric. Scand. B-S P 2018, 68, 39-49. [CrossRef]

13. Rigby, H.; Clarke, B.O.; Pritchard, D.L.; Meehan, B.; Beshah, F.; Smith, S.R.; Porter, N.A. A critical review of nitrogen mineralization in biosolids-amended soil, the associated fertiliser value for crop production and potential for emissions to the environment. Sci. Total Environ. 2016, 541, 1310-1338. [CrossRef]

14. Løes, A.-K.; Bünemann, E.K.; Cooper, J.; Hörtenhuber, S.; Magid, J.; Oberson, A.; Möller, K. Nutrient supply to organic agriculture as governed by EU regulations and standards in six European countries. Org. Agric. 2017, 7, 395-418. [CrossRef]

15. Gao, M.; Liang, F.; Yu, A.; Li, B.; Yang, L. Evaluation of stability and maturity during forced-areation composting of chicken manure and sawdust at different C/N ratios. Chemosphere 2010, 78, 614-619. [CrossRef] [PubMed]

16. Lopez, M.; Huerta-Pujol, O.; Martinez-Farre, F.X.; Soliva, M. Approaching compost stability from Klason lignin modified: Chemical stability degree for OM and N quality assessment. Resour. Conserv. Recycl. 2010, 55, 171-181. [CrossRef]

17. Jakubus, M. Evaluation of maturity and stability parameters of composts prepared with sewage sludge. Fresen. Environ. Bull 2013, 22, 3398-3414.

18. Ostrowska, A.; Gawliński, S.; Szczubialka, Z. Methods for Analysis and Evaluation of Soil and Plant Properties, 1st ed.; IOŚ Warszawa, 334: Warszawa, Poland, 1991; pp. 158-167. (In Polish)

19. Kononova, M. Soil Organic Substances, Their Structure Characteristics and Methods of Research, 1st ed.; PWRiL: Warszawa, Poland, 1968; p. 367. (In Polish)

20. Dziadowiec, H.; Gonet, S. A methodological guide to soil organic matter research. PTG 1999, 120, 43-51. (In Polish)

21. Mushtaq, M.; Iqbal, M.K.; Khalid, A.; Khan, R.A. Humification of poultry waste and rice husk using additives and its application. Int. J. Recycl. Org. Waste Agric. 2019, 8, 15-22. [CrossRef]

22. Polish Committee for Standarisation PN-EN ISO 11269-2; 2013-06. Part 2. Effects of Contaminated Soil on the Emergence and Early Growth of Higher Plants. In Determination of the Effects of Pollutants on Soil Flora; Polish Committee for Standarisation: Warszawa, Poland, 2013.

23. Tiquia, S.M. Reduction of compost phytotoxicity during the process of decomposition. Chemosphere 2010, 79, 506-512. [CrossRef] [PubMed]

24. Miaomiao, H.; Wenhong, L.; Xinqiang, L.; Donglei, W.; Guangming, T. Effect of composting process on phytotoxicity and speciation of copper, zinc and lead in sewage sludge and swine manure. Waste Manag. 2009, 29, 590-597. [CrossRef] [PubMed]

25. Regulation of the Minister of Agriculture and Rural Development of 18 June 2008. J. Laws 2008, 119, 765.

26. Commission Regulation (EC) No 889/2008. Available online: https://eur-lex.europa.eu/legal-content/EN/ TXT/PDF/?uri=CELEX:32008R0889\&from=EN (accessed on 2 May 2020).

27. Jakubus, M. Sewage Sludge. Origin and Administration, 1st ed.; Poznan University of Life Sciences Press: Poznań, Poland, 2012; pp. 1-56. (In Polish)

28. Bustamante, M.A.; Alburquerque, J.A.; Restrepo, A.P.; de la Fuente, C.; Paredes, C.; Moral, R.; Bernal, M.P. Co-composting of the solid fraction of anaerobic digestates, to obtain added-value materials for use in agriculture. Biomass Bioenerg. 2012, 43, 26-35. [CrossRef]

29. Zhang, L.; Sun, X. Evaluation of maifanite and silage as amendments from green waste composting. Waste Manag. 2018, 77, 435-446. [CrossRef] 
30. Shah, G.M.; Tufai, N.; Bakhat, H.F.; Ahmad, I.; Shahid, M.; Hammad, H.M.; Nasim, W.; Waqar, A.; Rizwan, M.; Dong, R. Composting of municipal solid waste by different methods improved the growth of vegetables and reduced the health risks of cadmium and lead. Environ. Sci. Pollut. Res. 2019, 26, 5463-5474. [CrossRef] [PubMed]

31. Azim, K.; Soudi, B.; Boukhari, S.; Perissol, C.; Roussos, S.; Alami, T. Composting parameters and compost quality: A literature review. Org. Agric. 2018, 8, 141-158. [CrossRef]

32. Antil, R.S.; Raj, D.; Abdalla, N.; Inubushi, K. Physical, Chemical and Biological Parameters for Compost Maturity Assessment. In Composting for Sustainable Agriulture; Dinesh, K., Ed.; Springer: New York, NY, USA; Dordrecht, The Netherlands; London, UK, 2014; pp. 83-102.

33. Asquer, C.; Cappai, G.; Gioannis, G.; Muntoni, A.; Piredda, M.; Spiga, D. Biomass ash reutilization as an additive in the composting process of organic fraction of municipal solid waste. Waste Manag. 2017, 69, 127-135. [CrossRef] [PubMed]

34. Bernal, M.P.; Paredes, C.; Sanchez-Mondero, M.A.; Cegarra, J. Maturity and stability parameters of composts prepared with a wide range of organic wastes. Bioresour. Technol 1998, 63, 91-99. [CrossRef]

35. Gomez-Brandon, M.; Lazcano, C.; Dominguez, J. The evaluation of stability and maturity during the composting of cattle manure. Chemosphere 2008, 70, 436-444. [CrossRef] [PubMed]

36. Singh, Y.K.; Kalamdhad, A.S.; Ali, M.; Kazmi, A.A. Maturation of primary stabilized compost from rotary drum composter. Resour. Conserv. Recycl. 2009, 53, 386-392. [CrossRef]

37. Raj, D.; Antil, R.S. Evaluation of maturity and stability parameters of composts prepared from agro-industrial wastes. Bioresour. Technol. 2011, 102, 2868-2873. [CrossRef]

38. Alvarenga, P.; Mourinha, C.; Farto, M.; Santos, T.; Palma, P.; Sengo, J.; Morais, M.C.; Cunha-Queda, C. Quality assessment of a battery of organic wastes and composts using maturity, stability and enzymatic parameters. Waste Biomass Valor. 2016, 7, 455-465. [CrossRef]

39. Iglesias-Jiménez, E.; Pérez-García, V. Determination of maturity indices for city refuse composts. Agric. Ecosyst. Environ. 1992, 38, 331-343. [CrossRef]

40. Ozdemir, S.; Dede, G.; Dede, O.H.; Turo, S.M. Composting of sewage sludge with mole cricket: Stability, maturity and sanitation aspects. Int. J. Environ. Sci. Technol. 2019, 16, 5827-5834. [CrossRef]

41. Jakubus, M.; Bakinowska, E. Practical applicability of germination index assessed by logistic models. Compost. Sci. Util. 2018, 26, 104-113. [CrossRef]

42. Kebrom, T.H.; Woldesenbet, S.; Bayabil, H.K.; Garcia, M.; Gao, M.; Ampim, P.; Awal, R.; Fares, A. Evaluation of phytotoxicity of three organic amendments to collard greens using the seed germination bioassay. Environ. Sci. Pollut. 2019, 26, 5454-5462. [CrossRef] [PubMed]

43. Sangamithirai, K.M.; Jayapriya, J.; Hema, J.; Manoj, R. Evaluation of in-vessel co-composting of yard waste and development of kinetic models for co-composting. Int. J. Recycl. Org. Waste Agric. 2015, 4, 157-165. [CrossRef]

44. Komilis, D.P.; Tziouvaras, I.S. A statistical analysis to assess the maturity and stability of six composts. Waste Manag. 2009, 29, 1504-1513. [CrossRef] [PubMed]

45. Ko, H.; Kim, K.; Kim, H.; Kim, C.; Umeda, M. Evaluation of maturity parameters and heavy metal contents in composts made from animals mature. Waste Manag. 2008, 28, 813-820. [CrossRef] [PubMed]

(C) 2020 by the author. Licensee MDPI, Basel, Switzerland. This article is an open access article distributed under the terms and conditions of the Creative Commons Attribution (CC BY) license (http://creativecommons.org/licenses/by/4.0/). 